\title{
Paródia, contestação e fruição em $O$ tetraneto del-rei de Haroldo Maranhão
}

\author{
Parody, Contestation and Fruition in O tetraneto del-rei by Haroldo Maranhão
}

Jonatas Alves da SILVA*

Secretaria Municipal de Educação de Castanhal-PA (SEMED)

\begin{abstract}
RESUMO: Este trabalho é a aceitação de dois desafios propostos pela leitura do romance $O$ tetraneto del-rei (1982), do paraense Haroldo Maranhão (1927-2004). O primeiro é entendê-lo como um texto de contestação, capaz de retomar os textos originais, desprendendo-os de seu contexto e atribuindo-lhes novos significados, indo além da questão da dependência cultural, ocupando o "entrelugar" mencionado por Silviano Santiago (1971), por meio de um texto que desconstrói a tradição, ultrapassando o particular para o universal. O segundo desafio é comprovar que esse romance é um exemplo do que Roland Barthes (2002) chamou de "texto de fruição", o que só será possível se primeiro for compreendido como uma paródia, e assim se possa perceber o distanciamento entre a paródia e o texto parodiado e, principalmente, compreender a ironia e a reflexividade que, conforme Linda Hutcheon (1989), caracterizam a paródia.
\end{abstract}

Palavras-chave: Haroldo Maranhão, Paródia, Contestação, Fruição.

Abstract: This work is the acceptance of two challenges proposed by reading the novel $\mathrm{O}$ tetraneto del-rei (1982), by Haroldo Maranhão (1927-2004). First is understand it as a text of challenged, able to resume the original texts, detaching them from their context and giving them new meanings, beyond the issue of cultural dependency, occupying the "entrelugar" mentioned by Silviano Santiago (1971), through a text that deconstructs the tradition, surpassing the particular to the universal. The second challenge is to prove that this novel is a example that Roland Barthes (2002) called "fruition text", which it will be possible only if the first understand as a parody, and thus can realize the distance between the parody and the parodied text and mainly, understand irony and reflexivity that according Linda Hutcheon (1989)

\footnotetext{
* Mestre em Estudos Literários pela Universidade Federal do Pará, Professor da Prefeitura Municipal Castanhal. Email: sojonatas@gmail.com 
characterizes the parody.

KeyWords: Haroldo Maranhão, Parody, Contestation, Fruition.

Tudo que dizemos tem um "antes" e um "depois" - uma "margem" na qual outras pessoas podem escrever.

Stuart Hall

O romance $O$ tetraneto del-rei (1982) de Haroldo Maranhão (1927-2004) nasce do passado, mas não no passado ${ }^{1}$. Foi escrito ao molde da língua portuguesa do século XVI, reconstituindo o passado histórico brasileiro, é crítica em ficção que alcançou um grande sucesso à época de seu aparecimento, tendo sido o vencedor do prêmio Guimarães Rosa, em 1980.

A obra retoma um contexto histórico e social, a colonização do Brasil, de forma irônica e crítica e, assim, paradoxalmente transcende-o por meio da releitura de textos recortados de diferentes contextos e épocas. O romance haroldiano, ao reescrever um determinado momento histórico, desconstrói valores constituídos pela historiografia tradicional (conquistadores da mais alta estirpe, "descobrimento", índios brasileiros pacíficos e manobráveis, etc.) mantendo sua atualidade.

O tetraneto del-rei é dividido em duas partes: O Litoral e Os Matos. Na primeira parte, toma-se logo consciência da existência de dois narradores. O primeiro narrador é aquele com quem o leitor tem o primeiro contato com a obra - narrador onisciente; o segundo é o próprio protagonista Jerónimo d'Albuquerque, o Torto, quando toma a primeira pessoa do discurso em suas cartas. Entre os dois, debate-se o leitor.

Mas antes de se arvorar na análise da obra, convém apresentar a ancoragem teórica na qual este trabalho se assegura. Para tanto, vale considerar as orientações de Antonio Candido, em seu livro Literatura e Sociedade, sobre qual abordagem metodológica optar: estética ou histórica? Para esclarecer, Candido expõe uma que

\footnotetext{
${ }^{1}$ Este artigo é, em grande parte, fruto de minha pesquisa de mestrado que resultou na dissertação Focalização em O tetraneto del-rei de Haroldo Maranhão, defendida em 2015 na UFPA. 
considera tanto a investigação do texto literário unicamente por seus fatores externos históricos e sociais - quanto uma que adota o percurso oposto, buscando investigar uma obra exclusivamente por seus fatores internos — formais. Sobre essa contradição, afirma Candido:

\begin{abstract}
Hoje sabemos que a integridade da obra não permite adotar nenhuma dessas visões dissociadas; e que só a podemos entender fundindo texto e contexto numa interpretação dialeticamente íntegra, em que tanto o velho ponto de vista que explicava pelos fatores externos, quanto o outro, norteado pela convicção de que a estrutura é virtualmente independente, se combinam como momentos necessários do processo interpretativo. Sabemos ainda que o externo (no caso, o social) importa, não como causa, nem como significado, mas como elemento que desempenha um certo papel na constituição da estrutura, tornando-se, portanto, interno. (2000, p. 04).
\end{abstract}

Abraçando essa concepção, esta análise tenta compreender, na estrutura formal, os aspectos externos ao texto, isto é, uma estrutura social nele representada. Por outro lado, apesar de "as obras se articularem no tempo, de modo a se poder discernir uma certa determinação na maneira por que são produzidas e incorporadas ao patrimônio de uma civilização" (CANDIDO, 2007), deve-se ter, como orienta Silviano Santiago (1989), o cuidado de não vacilar na armadilha do estudo realista do objeto artístico, condicionando nossa leitura do mesmo em um determinado tempo e espaço.

Também não se pode deixar de fazer uma análise comparativa, posto que a obra, sendo uma paródia, realiza um constante diálogo com outras obras e, na medida em que essas outras obras forem solicitadas pelo próprio texto - a essa relação entre textos, Genette $(2006)^{2}$ denomina de intertextos - vamos retomá-las, explicitando assim o processo de criação do autor, mas principalmente a fim de conduzir a leitura para o que Roland Barthes (2002) chama de prazer do texto. Antes, porém, um conceito de Literatura Comparada:

A literatura comparada é um ramo da história literária: ela é o estudo das relações espirituais internacionais, dos rapports de fait [relações de fato] entre

\footnotetext{
2 Vale ressaltar que nossa leitura se deu por meio dos extratos traduzidos do francês por Luciene Guimarães e Maria Antônia Ramos Coutinho submetidos ao trabalho de tradução realizado no âmbito de um Estudo Especial, no Programa de Pós-Graduação em Estudos Literários - POSLIT - da FALE/UFMG, em 2003. Segunda edição monolíngue em 2006. Disponível em <http://www.letras.ufmg.br/site/publicacoes/download/ palimpsestosmono-site.pdf> Acesso em $21 / 10 / 09$
} 
Byron e Pushkin, Goethe e Carlyle, Walter Scott e Alfred de Vigny, e entre as obras, as inspirações e até entre as vidas de escritores pertencentes a literaturas diferentes. (GUYARD, 1951, p. 5 apud WEISSTEIN, 1994)

Mas é preciso dizer que Literatura Comparada não existe sem uma prática comparativa que, na verdade, apresenta um âmbito e uma finalidade mais amplos e ambiciosos. Por "isso" há ênfase nos dados com os quais o leitor vai se deparar.

Voltando, então, aos narradores de $O$ tetraneto del-rei, é possível divisar que o primeiro narrador (onisciente) está sempre ali, ao pé dos portugueses, pronto para registrar suas gafes da maneira mais jocosa. Apresenta o herói com todos os seus defeitos e quase nenhuma qualidade, quase o oposto de Vasco da Gama, herói camoniano. A citação abaixo descreve uma das cenas mais emblemáticas do romance (o encontro dos portugueses com os ameríndios) e exemplifica bem o perfil desse narrador:

— Quem tem cuuuuuuuu tem meeeedo!

Quem se atreveria a sobre si mesmo chamar tamanha atenção? Que embuçada voz assi tão vivissimamente enunciava palavras tais, e de modo tão solene, escandidamente sinalando as sílabas - Quem tem cuuuuuuu tem meeeeedo!? Lançada aos ares, similhante advertência dispara tiro mais eficaz que um arcabuz. E como se à unanimidade fossem à bruta empurrados, e a um só tempo acudissem a um só sinal, saíram a correr com grandes gritas e alvoroços; e até hoje haverá portugueses alhures em debandada. À frente do pugilo apavorado, corria justo o capitão, e em seu couce vinha obra de oitenta ou mais portugueses. Distanciados da praia estavam a duas horas de caminho, porém o regresso foi abreviado pela metade ou até menos, quão enorme havia sido o empenho no escafederem-se (MARANHÃO, 1982, p. 15-16 - grifo meu).

A frase em discurso direto, e em Língua Portuguesa, sai do meio da mata e assombra os portugueses. Não tem como não notar o tom jocoso com que esse primeiro narrador relata os acontecimentos, esse tom chega ao extremo nas expressões "quão enorme havia sido o empenho em escafederem-se" e "e até hoje haverá portugueses alhures em debandada”. Nessa última expressão, o narrador dialoga diretamente com o leitor, pois o tempo da leitura não é o mesmo tempo da escrita. A quem pertence esse "hoje", ao leitor ou ao narrador? Ou será 
que pertence aos dois? É nesse jogo que o leitor vai se envolvendo e (pro)seguindo em direção aOs Matos.

Esse envolvimento do leitor, provocado pela própria obra, fazendo-o, vez por outra, levantar a cabeça, criar um intervalo no enredo da narrativa e repensar a questão histórica, a veracidade das crônicas do decobrimento do Brasil, em especial à Carta de Pero Vaz de Caminha, é o que faz dessa obra um exemplo do que Roland Barthes chama de texto de fruição, "aquele que põe em estado de perda, aquele que desconforta (talvez até um certo enfado), faz vacilar as bases históricas, culturais, psicológicas do leitor [...]" (2002, p. 20-21)

Da primeira para a segunda parte, Jerónimo d'Albuquerque sofre uma dupla perda: uma fantasia e um olho. O protagonista acreditava que facilmente ganharia a amizade dos índios:

\footnotetext{
Nas fantasias que construíra, o enamorado do sertão e de sua gente meteu a idéia de que dele o gentio se acercaria a ânimos dóciles, em termos de grandíssima amizade. E mais nesse propósito se fincava ao considerar que não mostrava armas de guerra, Era só o corpo munido de roupa; e o resto bom. (MARANHÃO, 1982, p. 115)
}

Mas o objetivo do Torto não era poupar a vida dos índios, e sim a de seus colegas e, principalmente, sua própria. Seu discurso está mais para um amedrontado que para um pacificador. Por outro lado, Jerónimo também almejava ver seu nome entre os mais ilustres de Portugal, aquele que conseguira evitar a guerra e pacificar o Novo Mundo. Mas o que veio a alcançar, tentando pacificar o encontro entre portugueses e índios brasileiros, foi tornar-se um cativo de olho vazado. Eis sua segunda perda. Jerónimo demora a ter consciência que se tornara caolho. Porém, depois de voltar a si, ainda cativo, o protagonista depara-se com "o arquiteto da ominosa correria pelos matos": Vasco Guedes, que depois de rir, ao lembrar da "debandada pânica", inicia um diálogo com o Torto:

- Fidalgote, disse-o bem. Fidalgote. Que teu sangue é tão rubro quanto o meu, segundo o bom parecer do Aracy, se acaso o perquerires. Sangue é sangue e aqui somos todos anspeçadas. És um anspeçada, isto: um anspeçada. E anspeçada sou eu. Estamos a ferro na mesma galeota, não passas de um orelhado. Um degredado infame entre os mais infames. É o que és. E o que 
sou. Dom! Dom de não-sei-o-quê! Dom de Peidos! Se és dom, sou eu D. Vasco Guedes. Vê lá: D. Vasco Guedes de Alcaparras, Conde de Cagalhõesao-Mar. Ou Visconde do Cu Redondo! Isto. D. Vasco Guedes de Alcaparras, Visconde do $\mathrm{Cu}$ Redondo. Somos trampa da mesma latrina. E vamos agora conversar. Lé com lé, cré com cré. Que te parece Jerónimo? (MARANHÃO, 1982, p. 129)

A esta altura, Jerónimo d'Albuquerque ainda insistia em se distinguir dos demais pelo sangue real, mas, como bem o esclarece Vasco Guedes, os dois não têm distinção alguma "segundo o bom parecer do Aracy", o índio que vazara o olho do português. As regras dOs Matos são outras. Contudo, o Torto não demora a aprender regras novas: casa-se com a filha do cacique Arco-Verde (para salvar a vida) e, assim, ganha a liberdade para outras relações amorosas.

DOs Matos que quase mataram o Torto, restou a perda do olho esquerdo. Mas esse olho a menos parece não representar uma desvantagem, ao contrário, a partir de então, Jerónimo passa a ter uma visão mais plena de seu estado. Conforme Chevalier e Gheerbrant, no Dicionário de símbolos "tradicionalmente, o olho direito (Sol) corresponde à atividade e ao futuro, o olho esquerdo (Lua) à passividade e ao passado" (2002, p. 654). Para entrar nOs Matos, Jerónimo precisou enfrentar seu medo (ter o "olho sinistro" ou "orificium ani" vazado) que tantas vezes o fizera sonhar tendo o "cu frechado" como se comprova no trecho abaixo:

$\mathrm{O}$ cu não era o cu, mas o sinistro olho que lhe estava a lançar, às faces, o poeta. Cujo lesado olho era o destro, e o esquerdo o do Albuquerque. O qual Albuquerque, por prezar os ambos da cara, é como se o molestassem no concernente ao do traseiro, já de si cego, e cuja prestança era na direitura de sair, nunca na de entrar (MARANHÃO, 1982, p. 121).

Jerónimo precisava ainda e, principalmente, esquecer seu passado (o sangue real). Como Tirésias, na mitologia grega, que perdeu a visão, mas foi compensado com o poder da (pré)visão, o Albuquerque perdera um olho, mas ganhou outra visão, de costa para o mar, olhar manco, mas capaz de ver o óbvio "- Índio é índio e português é português".

Depois de aportarem na praia, os portugueses, "salteados da febre do ouro, da 
prata e do âmbar" (MARANHÃO, 1982, p. 14), caminharam por duas horas terra à dentro, até verem-se cercados de índios. Esse primeiro encontro é narrado sob uma ótica divergente à dos cronistas do descobrimento. Ao contracanto, sempre se estende a voz, na mente do leitor, das muitas vozes, ecoando díspares ao fato, agora, narrado:

— Quem sois e o que desejais?, da parte de el-rei!

Esta ação meteu assombro nos acuados, que acuados eram, não os índios, mas os portugueses. Os quais atordoaram-se vivissimamente. Ao passo que o Torto como se o esperassem fomentos, nos rústicos se empregou os olhos em suma arrogância, tendo por pauta de seu procedimento o zelo pelo sangue preclaro do pentavô D. Diniz. (MARANHÃO, 1982, p.14 - grifo meu)

Esse é o primeiro momento em que o fidalgo Jerónimo d'Albuquerque começa a perceber (sem, contudo, convencer-se) que o que ele "trazia na bagagem", ou, neste caso, o que trazia nas veias, "sangue preclaro do pentavô D. Diniz", poderia não ser útil no Novo Mundo. Pelo trecho em destaque, já se pode ter uma clara impressão do tom que o texto toma ao longo do romance, e como a linguagem se vale da história para construção de uma nova história protagonizada por Jerónimo d'Albuquerque: "que acuados eram, não os índios, mas os portugueses".

O termo "acuado", conforme o Dicionário Houaiss da língua portuguesa (2001, p. 73), significa "cercado ou entocado por cães". Ora, se "acuados eram os portugueses", então estes eram os que estavam no papel de caça, afugentados, não como pintam os cronistas do descobrimento, apresentando os europeus como conquistadores.

Quando o escritor insere entre vírgulas a expressão "não os índios", ele dialoga com a história da colonização do Brasil que o leitor conhece consciente ou inconscientemente, estabelece um diálogo com o leitor, com as leituras do leitor. Ao deparar-se com essa passagem, o leitor passa a interrogar a sua própria leitura, e assim tece seu próprio texto, "simplesmente um texto, esse texto que escrevemos em nossa cabeça quando a levantamos", como diz, em o Rumor da Língua, Roland Barthes (2004, p. 27).

Mas esse texto do leitor é suscitado pela leitura da palavra, que, por sua vez, carrega ecos de outras, como ensina Stuart Hall:

As palavras são "multimoduladas". Elas sempre carregam ecos de outros significados que elas colocam em 
movimento, apesar de nossos melhores esforços para cerrar o significado. Nossas afirmações são baseadas em proposições e premissas das quais nós não temos consciência, mas que são, por assim dizer, conduzidas na corrente sanguínea de nossa língua. Tudo que dizemos tem um "antes" e um “depois" - uma “margem" na qual outras pessoas podem escrever (2006, p. 41).

É nessa margem mencionada por Stuart Hall que $O$ tetraneto del-rei é construído. É com o pé nessa margem que se nega o que ainda não foi mencionado na narrativa, como se já houvesse sido - e, na verdade, já o fora por outro, em outro tempo.

Antes de seguir, faz-se necessário abordar o conceito de paródia, para tanto, tomamos por base principalmente dois autores: Gerard Genette (2006) e Linda Hutcheon (1989), os dois tratando do mesmo assunto, ora divergem, ora se aproximam. Mas antes, é preciso prevenir que em vez de se fazer comparações apenas teóricas sobre os dois, optou-se neste trabalho por fazer uma abordagem do conceito já com exemplificação na obra em questão.

Para Gerard Genette (2006), em Palimpsesto, há paródias que consistem na alteração de uma letra em uma palavra; outras trocam uma palavra de um verso, por exemplo: "Minha terra tem palmares" de Oswald de Andrade, outras ainda, sem qualquer alteração textual, suprimem o sentido de uma citação, ao dar-lhes um novo contexto. O seguinte trecho da sexta carta de Jerónimo d'Albuquerque, seguido do poema Aqui, neste misérrimo desterro, de Ricardo Reis (heterônimo de Fernando Pessoa), ilustra muito bem essa categoria de paródia:

Senhora, estou cansado, é claro, porque, a certa altura, a gente tem que estar cansado. Um supremíssimo cansaço, íssimo, íssimo, íssimo, cansaço... Não. Cansaço por quê? Começo a conhecer-me. Não existo. Meu Deus, que fiz eu da vida? Tenho vontade de chorar, tenho vontade de chorar muito de repente, de dentro. Onde estais vós, que eu quero chorar de qualquer maneira? Aquele peso em mim - meu coração. A espantosa realidade das coisas é a minha descoberta de todos os dias. Aqui, neste misérrimo desterro onde nem desterrado estou, habito, fiel, sem que queira, aquele antigo erro pelo qual sou proscrito. (MARANHÃO, 1982, p. 46 - grifo meu) 
Aqui, neste misérrimo desterro

Aqui, neste misérrimo desterro

Onde nem desterrado estou, habito,

Fiel, sem que queira, àquele antigo erro

Pelo qual sou proscrito.

$\mathrm{O}$ erro de querer ser igual a alguém

Feliz, em suma — quanto a sorte deu

A cada coração o único bem

De ele poder ser seu.

(PESSOA, 2003, p. 290 - grifo meu)

Nota-se que os quatro primeiros versos do poema de Ricardo Reis foram "recortados e colados" na carta de Jerónimo d'Albuquerque, não havendo alteração alguma, senão no contexto. O termo "aqui", no poema, é um indicativo de estado da alma, o interior do eulírico. Já na carta, o advérbio toma mais um sentido, que é o local onde o Torto se encontra, ou seja, o Brasil.

Quando se comparam os sentidos dos termos "desterro", "proscrito" e "erro" também se percebe que os sentidos são outros. No poema, por exemplo, observa-se que o erro ao qual o eu-lírico refere-se é “O erro de querer ser igual a alguém”, que tem como consequência a ausência do ser amado, que é o seu "desterro", ou seja, aquilo que deixa o eu-lírico "proscrito". Contudo, na carta de Jerónimo d'Albuquerque, esse "erro" é uma referência à razão do seu "desterro" - que aqui tem outra acepção: ser banido de seu país. Essa razão é descrita logo nas primeiras linhas do romance: "Matérias galantes tê-lo-ão metido em estreito aperto por senhores grandes do reino, vítima de línguas malédicas e ameaçado de gravames." (MARANHÃO, 1982, p. 9).

As possibilidades de leituras da obra haroldiana são muitas, e esse caminho que estabelece comparações entre o texto escrito e os "pedaços" que o compõem já foi explorado por Silvio Holanda em $O$ sertão é dentro da gente: algumas anotações de torno da carta 8 de O tetraneto del-rei, publicado na Revista Asas da Palavra em 2002. Trata-se da comparação entre a carta 8 e Grande Sertão Veredas de Guimarães Rosa. Ainda sobre este mesmo viés, Aline Muniz em A recriação histórico-literária em $O$ tetraneto del-rei, artigo publicado em anais do IV Colóquio de Estudos Linguísticos e Literários, faz a comparação da carta 6 com 
poemas de Fernanda Pessoa.

Esse processo de recorte é "O que singulariza essa narrativa de Haroldo Maranhão é a extrema agudeza com que o autor recorta textos literários e históricos, que vão desde a carta inaugural de Caminha a Guimarães Rosa e João Cabral de Melo Neto” (HOLANDA, 2002, p. 75). Esse caminho está presente em toda a obra, logo nas primeiras linhas do romance, por exemplo, o narrador deixa claro que a razão da grande viagem não se faz pela bravata de querer navegar por "mares nunca dantes navegados". Não é por "glória de mandar, ó vã cobiça / desta vaidade a quem chamamos Fama!", mas sim para ter a salvo a pele, como deixa claro o trecho abaixo:

— I-vos muito embora. E fazei por vos salvar! Se este voto vos descontenta, embora de mim hajais fiado, eu vo-lo digo, D. Jerónimo, que melhor será tanger a vós para além mares do que vos tangerem para além, que desta última distância não teríeis regresso (MARANHÃO, 1982, p. 9).

Inevitável é a comparação com a fala do Velho do Restelo, estrofe 95 de Os Lusíadas:

Ó glória de mandar, ó vã cobiça

Desta vaidade, a quem chamamos Fama!

Ó fraudulento gosto, que se atiça

Cua aura popular, que honra se chama!

Que castigo tamanho e que justiça

Fazes no peito vão que muito te ama!

Que mortes, que perigos, que tormentas,

Que crueldades neles experimentas!

(CAMÕES, 2008, p. 142)

Enquanto o Velho do Restelo adverte para os males que os portugueses haveriam de encontrar além mar, "Que mortes, que perigos, que tormentas, / que crueldades ...”, Jerónimo d'Albuquerque é advertido de que os males que poderia encontrar além mar são infinitamente menores do que aqueles que já sobre si assoberbavam: "melhor será tanger a vós para além mares do que vos tangerem para além, que desta última distância não teríeis regresso".

$\mathrm{Na}$ estrofe 91 do épico português, toma vez a voz de uma esposa, reclamando a presença do esposo e reprovando sua partida:

Qual em cabelo: "Ó doce e amado esposo,

Sem quem não quis Amor que viver possa, 
Por que is aventurar ao mar iroso

Essa vida que é minha e não é vossa?

Como, por um caminho duvidoso,

Vos esquece a afeição tão doce nossa?

Nosso amor, nosso vão contentamento,

Quereis que com as velas leve o vento?

(CAMÕES, 2008, p. 141)

Em Os Lusíadas, a esposa indaga: "Por que is aventurar ao mar iroso / Essa vida que é minha, e não é vossa?", em O tetraneto del-rei, o "esposo" responde:

Pois Marco Aurélio lastimava-se do oneroso em que se constitui o matrimônio. Que maior carga não há para ombros de homem casado. Ele assinalava e assinalava com grã sabedoria que trinta anos ou mais fora solteiro: e os anos, dias pareceram-lhe. E dos cinco anos que fora casado a si pareceram quinhentos (MARANHÃO, 1982, p. 77).

Essa comparação entre a advertência dada a Jerónimo d'Albuquerque e a do Velho do Restelo ilustra o que Linda Hutcheon (1989), em Uma teoria da paródia, ao tratar do conceito de paródia, chama de "inversão irônica". Ela salienta que a paródia é uma forma de imitação, mas é "caracterizada por uma inversão irónica, nem sempre às custas do texto parodiado.[...] A paródia é, noutra formulação, repetição com distância crítica, que marca a diferença em vez da semelhança" (HUTCHEON, 1989, p. 17).

O termo paródia já foi empregado sem muita distinção, não basta ter entre dois textos uma relação de comparação com efeito cômico para ser denominado de paródia. Sobre essa “confusão", Gerard Genette declara:

A palavra paródia é correntemente um lugar de uma grande confusão, porque a usamos para designar ora a deformação lúdica, ora a transposição burlesca de um texto, ora a imitação satírica de um estilo. A principal razão desta confusão está evidentemente na convergência funcional dessas três fórmulas, que produzem em todos os casos um efeito cômico, geralmente às custas do texto ou do estilo "parodiado" [...]. Mas essa convergência funcional mascara uma diferença estrutural muito mais importante entre os estatutos transtextuais: a paródia estrita e o travestimento procedem por transformação de texto, o pastiche satírico (como todo pastiche), por imitação de estilo. (2006, p. 19-20).

Aliás, é na etimologia do termo paródia que 
Hutcheon (1989) entra em acordo com Gerard Genette. Este sugere, em Palimpsestos, uma nova nomenclatura para paródia, como se vê na citação abaixo:

Proponho, portanto, (re)batizar de paródia o desvio de texto pela transformação mínima [...]; travestimento, a transformação estilística com função degradante [...]; charge (e não mais, como já referido, paródia), o pastiche satírico, do qual À la manière de... são exemplos canônicos, e do qual o pastiche cômico-heróico é só uma variedade; e simplesmente pastiche, a imitação de um estilo desprovida de função satírica (GENETTE, 2006, p. 20)

Linda Hutcheon (1989) compreende, como Genette (2006), a paródia como uma relação formal ou estrutural entre dois textos, mas salienta que "mesmo que uma definição de paródia moderna comece por uma análise formal, não deve ficar por aí” (HUTCHEON, 1989, p. 34). Então, prossegue:

Quando falamos de paródia não nos referimos a dois textos que se inter-relacionam de certa maneira. Implicamos também uma intenção de parodiar outra obra (ou conjunto de convenções) e tanto um reconhecimento dessa intenção como capacidade de encontrar e interpretar o texto de fundo na sua relação com a paródia (HUTCHEON, 1989, p. 34).

Desse modo, Hutcheon (1989) vai deslizando para a semiótica pragmática de Umberto Eco por apresentar, conforme a autora, as ferramentas que permitem ultrapassar o formalismo de Genette, uma vez que

a paródia seria um dos "passos inferenciais", nos termos de Eco, têm de ser dados pelo receptor: "não são meras iniciativas caprichosas da parte do leitor, mas são antes suscitadas pelas estruturas discursivas e previstas por toda a estratégia textual como componentes indispensáveis da construção" da obra. (HUTCHEON, 1989, p. 34)

A paródia não envolve só um enunciado, mas todo o processo da enunciação, todo um contexto. Na leitura, só podemos inferir as intenções do escritor, partindo do texto, por exemplo, na expressão já mencionada "que acuados eram, não os índios, mas os portugueses", o leitor pode inferir que, ao se inserir a expressão "não os índios, mas" no interior da frase “que acuados eram os portugueses", há uma referência indireta à história da colonização do Brasil. Apesar de serem só inferências, não podem ser descartadas, pois delas dependem o prazer da ironia da paródia, pois, quanto mais empenhado for o leitor nesta ida-e-vinda de 
uma obra a outra(s), maior será o seu prazer. Afinal, conforme Roland Barthes:

Abrir o texto, propor o sistema de sua leitura, não é apenas pedir e mostrar que podemos interpretá-lo livremente; é principalmente, e muito mais radicalmente, levar a reconhecer que não há verdade objetiva ou subjetiva da leitura, mas há apenas verdade lúdica. (2004, p. 29).

Isso não quer dizer que leitura seja distração, ao contrário, alerta Barthes, "ler é fazer nosso corpo trabalhar [...] ao apelo dos signos do texto, de todas as linguagens que o atravessam e que formam como que a profundeza achamalotada da frase" (2004, p. 29). Aliás, esse momento em que o corpo segue suas próprias ideias é que constitui, conforme Roland Barthes (2002), "o prazer do texto", a "verdade lúdica".

Sobre essa mesma verdade da leitura, evoco as palavras de Antoine Compagnon: "O essencial da leitura é o que eu recorto, o que eu ex-cito; sua verdade é o que me compraz, o que me solicita" (1996, p. 33). Ele faz alusão às palavras do guarda florestal mencionado em O trabalho da citação, especificamente no capítulo O homem da tesoura: "Eu leio com a tesoura nas mãos, desculpem-me, e eu corto tudo o que me desagrada" (COMPAGNON, 1996, p. 32). Ora, se o leitor corta tudo o que lhe desagrada, só resta o que lhe dá prazer, e isso que lhe resta já não é mais o que leu, mas o que recortou e colou na parede da memória, é o seu próprio texto. Porém, isso não torna o leitor criador do texto que lê?

Para resposta da última indagação, Silviano Santiago, em Uma literatura nos trópicos, especificamente no ensaio $O$ entre-lugar do discurso latino-americano, assegura:

O texto segundo se organiza a partir de uma meditação silenciosa e traiçoeira sobre o primeiro texto, e o leitor, transformado em autor, tenta surpreender o modelo original nas suas limitações, nas suas fraquezas, nas suas lacunas, desarticula-o e o rearticula, de acordo com as suas intenções, segundo sua própria direção ideológica, sua visão do tema apresentado de início pelo original (SANTIAGO, 1971, p. 22 ).

$O$ tetraneto del-rei é um singular exemplo do que menciona Santiago acima, basta lembrar do episódio do encontro entre ameríndios e europeus, do qual destaco o trecho abaixo (à direita) tendo, a título de comparação, o que Santiago chama de "texto primeiro", que, neste caso, é um trecho da carta de Caminha (à esquerda):

e Nicolau Coelho lhes fez sinal que pousassem os arcos. E eles os pousaram. Ali não pôde deles haver fala, nem entendimento de proveito, por o mar quebrar na costa. Deu-lhes somente um 
barrete vermelho e uma carapuça de linho que levava na cabeça e um sombreiro preto. $E$ um deles deu-lhe um sombreiro de penas de ave, compridas, com uma copazinha de penas vermelhas e pardas, como de papagaio. (CAMINHA, 2002, p. 93 - grifo meu).

Em rasgo de altiva nobreza, da cabeça arrancou o fino chapéu e arremessou-o no rumo de um rol de nus. Com cuja bravata curava despertar uma pouca de hospitalidade. Jazido em terra ficou o tricórnio chapéu, o que D. Jerónimo entendeu por mau anúncio. De natural seria que o supremo senhor daquelas gentes, ripostando a homenagem amical, lhe atirasse o próprio cocar de penas encarnadas, sinal do seu generalato (MARANHÃO, 1982, p. 15 - grifo meu).

Merecem destaque, neste episódio, os gestos com os quais os personagens Nicolau Coelho e Jerónimo d'Albuquerque entram em comunicação com os ameríndios. Na carta de Caminha, se descreve a ação seguida de sucesso, uma resposta positiva, em $O$ tetraneto del-rei a ação do Torto leva a resultado nenhum, o que força ao protagonista "retomar a desfeiteada prenda". Comparando, percebe-se que "O texto segundo se organiza a partir de uma meditação silenciosa e traiçoeira sobre o primeiro texto". E o leitor, que fica entre o primeiro e o segundo texto, pode (des)articular o texto primeiro “de acordo com as suas intenções, segundo sua própria direção ideológica, sua visão do tema apresentado de início pelo original" (SANTIAGO, 1971, p. 22).

Destaca-se ainda, desse mesmo trecho, a seguinte passagem: "De natural seria que o supremo senhor daquelas gentes, ripostando a homenagem amical, lhe atirasse o próprio cocar de penas encarnadas, sinal do seu generalato". De que naturalidade menciona o narrador referindo-se à reação do "supremo senhor"? A ironia é a chave dessa naturalidade, ironia que se acentua e se explicita quando se põe lado a lado o "texto original" e "texto segundo".

Para prosseguir, faz-se necessário ir a uma dupla classificação de texto literário dada por Roland Barthes (textos legíveis e textos escrevíveis), em $S / Z$, conforme, ainda, orientação de Santiago:

O texto legível é o que pode ser lido, mas não escrito, não reescrito, é o texto clássico por excelência, o que convida o leitor a permanecer no interior de seu fechamento. Os outros textos, os escrevíveis, apresentam, ao contrário, um modelo produtor (e não 
representacional) que excita o leitor a abandonar sua posição tranquila de consumidor e a se aventurar como produtor de textos (SANTIAGO, 1971, p. 21).

Esse texto que excita o leitor convida-o para a práxis, o despertando, o radicalizado, o transformando em autor, o colocando na posição de criador. Esse texto "escrevível" é dependente do leitor, é composto de lacunas. Por outro lado, essa dependência do texto em função do leitor não ocorre de modo desorganizado, aleatório, pois a leitura, por

mais subjetiva que se possa imaginar nunca passa de um jogo conduzido a partir de certas regras. De onde vêm essas regras? Não do autor, por certo, que não faz mais do que aplicá-la à sua moda (...); visíveis muito aquém dele, essas regras vêm de uma lógica milenar da narrativa (BARTHES, 2004, p. 28-29)

O que faz então o escritor? Se o escritor for latino-americano, Santiago (1971) afirma:

O escritor latino-americano brinca com os signos de um outro escritor, de uma outra obra. As palavras de outro têm a particularidade de se apresentarem como objetos que fascinam seus olhos, seus dedos, e a escritura do texto segundo é em parte a história de uma experiência sensual com o signo estrangeiro. (SANTIAGO, 1971, p. 23)

Mais uma vez volta-se a Barthes (2004), ele trata de uma "verdade lúdica" (a do leitor), Santiago, fazendo menção a Sartre - que muito bem se emprega também a Haroldo Maranhão -, retoma o lúdico, mas do lado do escritor que brinca, que monta seu brinquedo a partir de peças já existentes (o já escrito), mas que, desse modo, cria um novo brinquedo, como uma criança com um lego. Aliás, terminada a brincadeira/leitura, faz-se um convite ao leitor-criador: desmonte e crie seu próprio brinquedo, sua própria obra. Ficar parado contemplando o já-feito não tem o mesmo prazer que desmontar e começar a brincadeira.

$O$ tetraneto del-rei, que é um texto de jogar, de brincar, levou a Comissão Julgadora do VI Prêmio Guimarães Rosa/1980 a dar o seguinte parecer ${ }^{3}$ ao romance de

\footnotetext{
${ }^{3}$ Este parecer foi publicado na orelha de $O$ tetraneto del-rei. Não se espante o leitor se, acaso, não encontrar essa orelha no exemplar que tenha adquirido, pois, alguns exemplares, por erro de corte, 
Haroldo Maranhão:

$O$ Tetraneto del-rei preenche coerentemente as exigências do indispensável diálogo entre autor e leitor. Nesse texto, o tributo devido à expressão e à comunicação se faz conscientemente realizado (...). Há, pois, uma exata correspondência entre linguagem e fabulação, que responde às necessidades de fundação de uma realidade nova - o romance/paródia/picaresco - que aparece então como um universo próprio a envolver capciosamente e inteligentemente o leitor.

Em $O$ tetraneto del-rei, o prazer do texto é dispensado ao leitor, por múltiplas possibilidades: de (des)construir a história da colonização do Brasil; de (des)dobrar a língua pela viagem à linguagem do século XVI; e de precisar (inter)romper a leitura para gargalhar sob o efeito da estúpida passagem do tom sério ao jocoso. Neste romance, o leitor pode brincar, rir e se divertir.

E como o romance foi construído tal qual se constrói um mosaico, com partes de outro, mas com uma forma própria, tal como um artista plástico que dos pedaços de outras obras faz a sua própria, Haroldo Maranhão encontrou, nos pedaços de outras, a sua obra-prima. A leitura do recorte mencionada por Antoine Compagnon (1996), em $O$ trabalho da citação, ilustra bem o processo de criação do romancista paraense que, tendo consciência de que "O essencial da leitura é o que eu recorto, o que eu ex-cito...", faz questão de dizer em nota, no seu livro, de quais autores se valeu para tecer seu texto:

No texto, há enxertos de versos e passagens de Fr. Amador Arrais, Pero Vaz de Caminha, Bocage, Gregório de Matos, Fr. Francisco de Mont'Alverne, Camilo Castelo Branco, Antero de Quental, Eça de Queiroz, Machado de Assis, Francisco Otaviano, Olavo Bilac, Fernando Pessoa, João Guimarães Rosa, Manuel Bandeira, Carlos Drummond de Andrade, João Cabral de Melo Neto, Mario Faustino e Lêdo Ivo (MARANHÃO, 1982).

Como um romance pós-moderno, $O$ tetraneto del-rei traz à tona a reflexão sobre os conceitos de "pureza" ou "unidade" na cultura ocidental. Sobre isso, orienta Silviano Santiago, em Uma literatura nos trópicos, especificamente no ensaio $O$ entre-lugar do discurso latino-americano:

acredito, ficaram sem as preciosas orelhas tais quais as vítimas do bibliófilo - personagem da terceira narrativa de Senhoras \& Senhores, obra de Haroldo Maranhão - que cortava e salgava orelhas de livreiros. 
A maior contribuição da América Latina para a cultura ocidental vem da destruição sistemática dos conceitos de unidade e de pureza: estes dois conceitos perdem o contorno exato do seu significado, perdem seu peso esmagador, seu sinal de superioridade cultural, à medida que o trabalho de contaminação dos latino-americanos se afirma, se mostra mais e mais eficaz. (1971, p. 18).

Santiago (1971) conduz de volta à epígrafe deste trabalho, "Não existe nada como 'originalidade' literária, nada como a 'primeira' obra literária: toda literatura é 'intertextual"'.

Afinal "Todos os textos literários são tecidos a partir de outros textos literários" (EAGLETON, 1983, p. 148).

O romance haroldiano, sendo uma paródia da colonização do Brasil, põe em xeque o atributo de verdade com o qual se tomou as crônicas de viagens. Isso corrobora com a indagação de Iser: "Os textos ficcionalizados serão de fato ficcionais e os que não se dizem serão de fato isentos de ficção?" (1983, p. 957). Haroldo Maranhão inicia sua obra com uma epígrafe irônica que já denuncia isso: “A verdade passa como tenho contado", de André Resende - História da Antiguidade da cidade de Évora.

Essa epígrafe, já no início da obra, chama a atenção para o conceito de verdade, porém atrelado a um narrador. Ao mesmo tempo em que tenta convidar o leitor para confiar naquilo que será contado, também deixa margem para inferir que a verdade só existe porque foi contada por alguém, como se dependesse da narração para tornar-se verdade. Anatol Rosenfeld, em sua obra Texto/Contexto, assegura que "As verdades são ficções de que se esquece que o são, metáforas gastas, moedas que perderam a sua imagem. Falar a verdade significa usar as metáforas usuais, isto é, diz a verdade de quem mente conforme convenções firmemente estabelecidas" (ROSENFELD, 1976, p.16). Desse modo, aceitar o convite de Maranhão pode ser "mergulhar" numa narrativa que, quer com mentiras, quer com verdade, pode conduzir o leitor para outra visão de um período muito importante para a formação do Brasil: o período colonial.

No romance em análise, o protagonista envia várias cartas a sua amada, em Portugal. Essa inserção de um gênero (carta) em outro gênero (romance) não é por acaso, é um modo de questionar a história da colonização do Brasil. A maioria das cartas do romance conduz sempre para esta reflexão: onde está a verdade? Será que 
posso confiar na verdade da História, ou a História é, na verdade, uma versão, quase sempre, dos opressores? Mas, afinal, conforme Karlherinz Stierle (2006, p. 89): “A escrita da história é ficção, não no sentido de informação enganosa, acriticamente modelada, mas sim no outro sentido do fingere como configuração necessária, mais ou menos feliz e objetiva, porém nunca inerente ao próprio objeto". Desse modo, a história não seria a história dos fatos, mas a narrativa dos fatos, uma ficção.

O Tetraneto del-rei, como paródia da colonização do Brasil, vai desconstruindo a história da colonização que por muito tempo foi ensinada. Na escola, ensinaram que o Brasil foi descoberto, em 1500, pelo navegador português Pedro Alvares Cabral. O fato é tão marcante para a história do Brasil que a crônica de Pero Vaz de Caminha passou a ter status de obra literária e, ao mesmo tempo, documento histórico. É ainda considerada uma espécie de certidão de nascimento do Brasil. O ano de 1500 é tão relevante que, no ano 2000, o governo brasileiro fez campanha publicitária para comemorar os 500 anos do Brasil, com direito a cédula comemorativa de dez reais, com o texto: "Brasil: 1500 - 2000", conforme se constata na imagem abaixo:

Figura 1: Reverso da cédula comemorativa dos 500 anos do "Descobrimento" do Brasil ${ }^{4}$

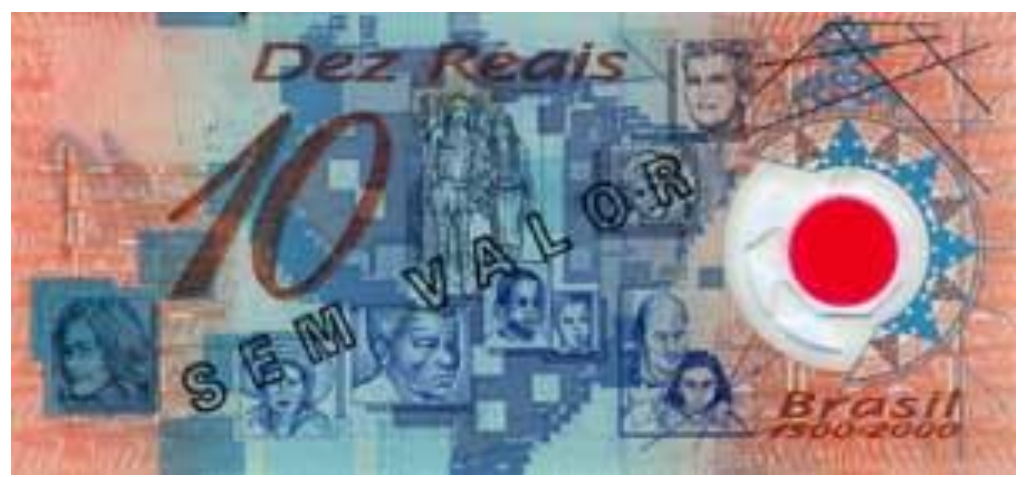

Para completar, no site do Banco Central do Brasil, está escrito, ao lado da imagem do anverso da cédula: “Contém a efígie de Pedro Álvares Cabral, navegador português que descobriu o Brasil em 22 de abril de 1500". A mensagem vai sendo inculcada, sem deixar margem para outra possibilidade, para outra versão da história do Brasil. A obra de Haroldo Maranhão, ao se contrapor a essa visão, traz, no mínimo, o questionamento: será verdade a história oficial? Será que existe apenas uma verdade?

\footnotetext{
${ }^{4}$ Disponível no site do Banco Central do Brasil: http://www.bcb.gov.br/htms/mecir/cedulas/500anos.asp. Acesso em 25/11/2015. 
Figura 2: Anverso da cédula comemorativa dos 500 anos do "Descobrimento" do Brasil $^{5}$

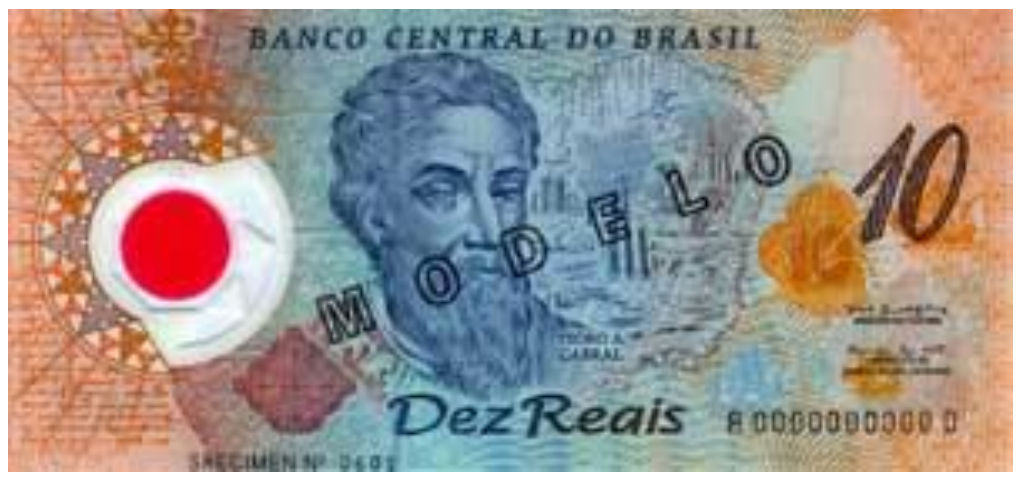

O brasileiro conta (no duplo sentido da palavra) sua história a partir de uma ótica do dominador, mesmo com evidência, na carta de Caminha, de que já havia um povo habitando essas terras. O Tetraneto Del-Rei, por outro lado, questiona tudo isso, desconstrói essa visão, pois coloca os habitantes daqui em pé de igualdade, ou até de superioridade, com os portugueses. Sobre essa desconstrução Sérgio Alves (2006, p.178) comenta:

o romance se reporta à descoberta do Brasil, podendo-se dizer que, ao espelhar o baixo das atitudes e feitos de um anti-herói, cujo traço está bem próximo do pícaro, constitui uma desconstrução da história criada pelos textos que assinalam as grandes aventuras.

O Tetraneto Del-Rei é uma forma de crítica que bem se adequa ao comentário de Hutcheon sobre paródia, pois tem a "vantagem de ser simultaneamente uma recriação e uma criação" (1989, p.70), faz da crítica uma exploração ativa da forma: a paródia. Em seu artigo Apesar de dependente, universal, Silviano Santiago (1982, p. 24) argumenta que "nas culturas periféricas, os textos descolonizados questionam, na própria fatura do produto, o seu estatuto e o estatuto do avanço cultural do colonizador". É justamente por essa "resposta a essa representação no próprio nível da fabulação" que o texto da cultura dominada é mais rico que o da cultura dominante, como frisa Santiago (1982, p. 23):

\footnotetext{
5 Idem 


\begin{abstract}
Paradoxalmente, o texto descolonizado (frisemos) da cultura dominada acaba por ser o mais rico (não do ponto de vista de uma estreita economia interna da obra) por conter em si uma representação do texto dominante e uma resposta a essa representação no próprio nível da fabulação, resposta esta que passa a ser um padrão de aferição cultural da universalidade tão eficaz quanto os já conhecidos e catalogados.
\end{abstract}

Aliás, o romance se vale de dois dos três "antídotos" contra o enciclopedismo europeocêntrico mencionados por Santiago (1982). O primeiro é a "noção malintencionada de antropofagia cultural brilhantemente inventada por Oswald de Andrade, num desejo de incorporar, criativamente, a sua produção dentro de um movimento universal" (SANTIAGO, 1982, p. 21). O segundo antídoto é a "noção de "traição da memória', eruditamente formulada por Mário de Andrade através das suas pesquisas em músicas com vistas a uma produção nacional popular." (SANTIAGO, 1982, p. 21). Esse “antídoto" é apresentado por Mário de Andrade quando, ironicamente, responde à acusação (velada) de plágio que Raimundo Morais fizera em seu Dicionário de Cousas da Amazônia 6 . A seguir a resposta:

O meu principal defeito intelectual, falha espantosa pela sua enormidade, é a falta de memória. Não tenho absolutamente memória nenhuma, mas absolutamente nenhuma (...). Mas toda a minha erudição está nas fichas ou dorme nos volumes. Em mim só conservo melancolicamente como que um salão depois do baile. Pelos riscos no chão, pelas migalhas, pela desordem das cadeiras, a gente percebe que muita coisa se passou ali. (ANDRADE, 1931 apud SOUZA, 1999, p. 36)

O tetraneto del-rei é tecido com fios de outro tempo, "fios da memória", como o título do trabalho de Alves (2006), fios do tear do leitor-criador. Fios de outros textos, fios que provam que "pureza" ou "unidade" na literatura nunca existiu, das primeiras grandes obras da literatura ocidental, Ilíada e Odisséia, nunca se provou autoria, de fato, de Homero, outros especulam que Homero foi apenas um compilador de narrativas

\footnotetext{
${ }^{6}$ A seguir a transcrição do verbete de Raimundo Moraes: "Os maldizentes afirmam que o livro Macunaíma do festejado escritor Mário de Andrade é todo inspirado no Von Roraima Zum Orenoco do sábio (Koch-Grünberg). Desconhecendo eu o livro do naturalista germânico, não creio nesse boato, pois o romancista patrício, com quem privei em Manaus, possui talento e imaginação que dispensam inspirações estranhas." (apud SOUZA, 1999, p. 34)
} 
orais, mas dizer "apenas" é desconhecer o árduo trabalho de construir um texto sobre (por cima do) outro. Dizer que Homero foi um grande compilador não o desmerece, de modo algum, ao contrário, faz dele um grande escritor, com todas as letras, pontos e vírgulas.

Para finalizar, cito Benedito Nunes, em texto que compõe a orelha de $O$ tetraneto del-rei:

\begin{abstract}
A aventura maior desta obra, resumo de suas proezas, que descendem em linha reta da Carta às Icamiabas, é proporcionar-nos o prazer do texto num texto de prazer. O gozo da história confunde-se com a fruição da linguagem numa narrativa inteiriça, destinada a ocupar proeminente lugar dentro do espaço da língua portuguesa - pátria comum de Guimarães Rosa e Camões, de Fernando Pessoa e Mário de Andrade.
\end{abstract}

Benedito Nunes põe Haroldo Maranhão ao lado dos grandes nomes da literatura de língua portuguesa, acentuando que o espaço é conquistado por $O$ tetraneto del-rei ser capaz de oferecer, ao leitor, "o gozo da história com a fruição da linguagem", mas, principalmente, porque "a aventura maior desta obra é proporcionar-nos o prazer do texto num texto de prazer". A “aventura maior” não está na obra em si, mas na re(1)ação com o leitor, na margem entre a obra e o leitor, na fenda cuja ponte é de mão dupla, de "idas e venidas".

Talvez o leitor tenha estranhado a maneira como foi abordada a fruição, não se dedicou um tópico exclusivamente à abordagem da mesma. Essa escolha se deu em função de a fruição não surgir de maneira isolada na leitura da obra, por meio de um trecho especificamente, mas por ser perceptível no decorrer da leitura, ou até, nas pausas da leitura. A fruição não está apenas na contestação, tampouco só na paródia, permeia a obra de Haroldo Maranhão do início ao fim. É o fio que permite a leitura lúdica, as paradas para repensar o conhecimento do leitor. A fruição acontece entre as idas e vindas em direção ao texto.

Este trabalho é senão mais uma "ida", uma tentativa de tecer, na fenda entre a contestação e a paródia, uma teia, algo capaz de mostrar alguns nós do tecido haroldiano. Talvez não tenha saído um tecido fino, mas o alinhavado aqui teve a pretensão de aguçar o olhar do leitor de $O$ tetraneto del-rei, conduzi-lo pelo emaranhado da paródia, pela mescla de linguagem, pelo estilo seicentista. 
Se este texto foi capaz de levantar o olhar do leitor, de provocar uma mudança de ângulo de visão, de conduzir à reflexão provocada pelo próprio tecido haroldiano, se inquietou e fez renascer a vontade de ler mais uma vez o romance do escritor paraense, então valeu a pena a leitura e a escrita.

\section{Agradecimentos}

À Profa. Dra. Socorro Simões, por deixar sempre aberta a porta do seu vasto conhecimento.

\section{REFERÊNCIAS}

ALVES, S.A.G. Fios da memória, jogo textual e ficcional de Haroldo Maranhão. 233f. Tese (doutorado em estudos literários) - Faculdade de Letras da Universidade Federal de Minas Gerais, Belo Horizonte, 2006.

BARTHES, R. O prazer do texto. Trad. J. Guinsburg. 3 ed. São Paulo: Perspectiva, 2002.

BARTHES, R. O rumor da língua. Trad. Mario Laranjeira. 2 ed. São Paulo: Martins Fontes, 2004.

CAMINHA, P. V. de. Carta de Pero Vaz de Caminha: a El-Rei D. Manuel sobre o Achamento do Brasil. São Paulo: Martin Claret, 2002.

CAMÕES, L.V. de. Os Lusíadas. Organização, apresentação e notas de Jane Tutikian Porto Alegre: L\&PM, 2008.

CANDIDO, A. Literatura e sociedade. São Paulo: T.A Queiroz Editor, 2000. . Formação da literatura brasileira: momentos decisivos 1750-1880. 11 ed. Rio de Janeiro: Ouro sobre Azul, 2007.

CHEVAliER, J; GHEERBRANT, A. Dicionário de símbolos. Trad. Vera da Costa e Silva. 17 ed. Rio de Janeiro: José Olympio, 2002.

COMPAGNON, A. O trabalho da citação. Trad. Cleonice 
P.B. Mourão. Belo Horizonte: Editora UFMA, 1996.

EAGLETON, T. Teoria da literatura, uma introdução. Trad. Waltensir Dutra. São Paulo: Martins Fontes, 1983.

GENETTE, G. Palimpsesto. Trad. Luciene Guimarães e Maria Antônia Ramos Coutinho, 2006. Disponível em: <http://www.letras.ufmg.br/site/publicacoes/download/ palimpsestosmono-site.pdf> Acesso em: 9 dez. 2009.

HALL, S. A identidade cultural na pós-modernidade. Trad. Tomaz Tadeu da Silva, Guaraeira Lopes Louro. 11 ed. Rio de Janeiro: DP\&A, 2006

HOLANDA, S. O sertão é dentro da gente: algumas anotações em torno da carta 8 de $\mathrm{O}$ tetraneto Del-Rei. In: Asas da palavra. Belém: Unama, v. 6, p. 75-77, 2002.

HOUAISS, A.; VILLAR, Mauro Salles. Dicionário Houaiss da língua portuguesa. Rio de Janeiro: Objetiva, 2001.

HUTCHEON, L. Uma teoria da paródia. Trad. de Teresa Louro Pérez. Lisboa: Edições 70, 1989.

HUTCHEON, L. Poética do pós-modernismo: história, teoria, ficção. Rio de Janeiro: Imago, 1991.

ISER, W. Problemas da teoria da literatura atual: o imaginário e os conceitos-chaves da época. Trad. Luiz Costa Lima. In: COSTA LIMA, L. Teoria da literatura em suas fontes. 2. ed. Vol. II. Rio de Janeiro: Francisco Alves, 1983.

MARANHÃO, H. O tetraneto del-rei. Rio de Janeiro: Francisco Alves, 1982.

MARANHÃO, Haroldo. Senhoras e senhores. Rio de Janeiro: Francisco Alves, 1989.

MUNIZ, Aline. A recriação histórico-literária em O Tetraneto Del-Rei. In: Anais Colóquio Internacional de Estudos Linguísticos e Literários - CIELLI. Maringá, 2010.

NUNES, Benedito. Orelha do livro. In: MARANHÃO, Haroldo. O Tetraneto Del-Rei. Rio de Janeiro: Francisco Alves, 1982. 
PESSOA, F. Obra Poética. Organização, introdução e notas de Maria Aliete Galhoz. 3 ed. Rio de Janeiro: Nova Aguilar, 2003.

ROSENFELD, Anatol. Texto/Contexto. 3 ed. Perspectiva. São Paulo, 1976.

SANTIAGO, S. O entre-lugar do discurso latino-americano. In: Uma literatura nos trópicos. São Paulo: Perspectiva, 1971. p. 11 - 28

Para além da história social. In: Nas Malhas da Letra. São Paulo: Companhia das Letras, 1989. p. 215 - 232.

Apesar de dependente, universal. In: Vale quanto pesa: ensaios sobre questões político-culturais. Rio de Janeiro: Paz e Terra, 1982.

SILVA, J.A. da. Focalização em O tetraneto del-rei de Haroldo Maranhão. 2015. 82 f. Dissertação (mestrado em estudos literários) - Faculdade de Letras da Universidade Federal do Pará, Belém, 2015.

SOUZA, E.M. A pedra mágica do discurso. 2 ed. rev. e ampl. Belo Horizonte: Ed. UFMG, 1999.

STIERLE, K. A ficção. Trad. Luiz Costa Lima. In: Novos cadernos do mestrado. Vol. 1. NUÑES, C.F.P.; SANTOS, F.V. dos (orgs.). Rio de Janeiro: Caetés, 2006.

WEISSTEIN, U. Literatura Comparada: uma definição. In: COUTINHO, E.F.; CARVALHAL, T.F. (org.). Literatura Comparada: textos fundadores. Rio de Janeiro: Rocco, 1994. 